\title{
Parietal Cell
}

National Cancer Institute

\section{Source}

National Cancer Institute. Parietal Cell. NCI Thesaurus. Code C12594.

A large epithelial cell located in the mucous membrane of the stomach that secretes gastric intrinsic factor and hydrochloric acid. 